\title{
The dynamics of questing ticks collected for 164 consecutive months off the vegetation of two landscape zones in the Kruger National Park (1988-2002). Part III. The less commonly collected species
}

\author{
Authors: \\ Gordon J. Gallivan ${ }^{1}$ \\ Andrea Spickett ${ }^{2}$ \\ Heloise Heyne ${ }^{2}$ \\ Arthur M. Spickett ${ }^{2}$ \\ Ivan G. Horak ${ }^{3,4}$ \\ Affiliations: \\ ${ }^{1} 187$ Cluny Street, Ottawa, \\ Canada \\ ${ }^{2}$ Parasites, Vectors \\ \& Vector-borne \\ Diseases Programme, \\ Onderstepoort Veterinary \\ Institute, South Africa \\ ${ }^{3}$ Department of Veterinary \\ Tropical Diseases, \\ University of Pretoria, \\ South Africa \\ ${ }^{4}$ Department of Zoology \\ and Entomology, University \\ of the Free State, \\ South Africa \\ Correspondence to: \\ Ivan Horak \\ Email: \\ ivan.horak@up.ac.za \\ Postal address: \\ Private bag X04, \\ Onderstepoort 0110, \\ South Africa \\ Dates: \\ Received: 09 Sept. 2010 \\ Accepted: 02 Feb. 2011 \\ Published: 19 Apr. 2011 \\ How to cite this article: \\ Gallivan, G.J., Spickett, \\ A., Heyne, H., Spickett, \\ A.M. \& Horak, I.G., 2011, \\ 'The dynamics of questing \\ ticks collected for 164 \\ consecutive months off \\ the vegetation of two \\ landscape zones in the \\ Kruger National Park \\ (1988-2002). Part III. The \\ less commonly collected \\ species', Onderstepoort \\ Journal of Veterinary \\ Research 78(1): Art. \#41, \\ 9 pages. doi:10.4102/ojvr \\ v78i1.41
}

Despite many studies regarding tick ecology, limited information on long-term changes in tick populations exist. This study assessed the long-term population dynamics of the less frequently collected questing ixodid ticks in the Kruger National Park (KNP). From 1988 to 2002, monthly dragging of the vegetation was performed in three habitats (grassland, woodland and gully) at two sites in the KNP (Nhlowa Road, Landscape Zone 17, and Skukuza, Landscape Zone 4). Amblyomma marmoreum and Rhipicephalus evertsi evertsi were collected as larvae most commonly. Most A. marmoreum larvae were collected at Skukuza and numbers peaked from March to July. More $R$. evertsi evertsi larvae were collected at Nhlowa Road and numbers peaked in summer and in winter, while at Skukuza there was a single peak in spring. Haemaphysalis elliptica, Rhipicephalus simus and Rhipicephalus turanicus were collected as adults most commonly. More Ha. elliptica and R. turanicus were collected at Nhlowa Road than at Skukuza, while $R$. simus numbers from the two sites were approximately equal. Ha. elliptica were collected most often between February and June, and R. simus and $R$. turanicus during February and March. All three species were collected more frequently in gullies than in grassland or woodland. Their numbers increased in 1994/1995 following an eruption of rodents, the preferred hosts of the immature stages. The different host-seeking strategies of ticks largely determine the development stage at which they are likely to be collected during vegetation dragging and reflect a complex interaction between ticks, their hosts and the environment.

\section{Introduction}

Many studies have examined the association between ticks, their hosts and the environment, but most have been of relatively short duration (typically 1-2 years) and there is little information on longer-term changes in tick populations. In earlier publications (Horak, Gallivan \& Spickett 2011; Spickett, Gallivan \& Horak 2011) we described changes in the numbers of questing ticks and the population dynamics of the four major tick species, Amblyomma hebraeum, Rhipicephalus appendiculatus, Rhipicephalus decoloratus and Rhipicephalus zambeziensis. The questing ticks were collected monthly by dragging flannel strips over the vegetation at two sites in the Kruger National Park (KNP) over a period of 164 months. In the present publication we describe changes in the numbers of the less commonly collected species, namely Amblyomma marmoreum, Dermacentor rhinocerinus, Haemaphysalis elliptica, Hyalomma truncatum, Rhipicephalus evertsi evertsi, Rhipicephalus simus and Rhipicephalus turanicus.

\section{Materials and methods}

The KNP is a large nature reserve of nearly 2 million ha in north-eastern South Africa. Five vegetation types (Acocks 1988) and 35 Landscape Zones (Gertenbach 1983) have been identified in the reserve. The study sites at Skukuza and Nhlowa Road and the associated climate, methods of tick collection and statistical analyses have been described in detail by Horak et al. (2011). The climate in the southern KNP is described as tropical with summer rainfall. Annual rainfall is measured from June to May; consequently, we have chosen June to represent the commencement of each year.

Briefly, questing ticks were collected monthly by drag-sampling the vegetation with flannel strips (Spickett et al. 1992) at two sites in the KNP, namely Nhlowa Road and Skukuza. The Nhlowa Road site was in Landscape Zone 17, which has been described as a Sclerocarya caffra-Acacia nigrescens savanna, and the Skukuza site in Landscape Zone 4 (Thickets of the Sabie and Crocodile Rivers). 
Three drags, approximately $250 \mathrm{~m}$ long and $1 \mathrm{~m}$ wide, were made at a normal walking speed in each of three visually selected habitats (grassland, woodland and gully) at each site. In addition to the flannel strips, the operator responsible for dragging the strips also wore flannel leggings. Because of the limited number of gullies at each site, the same gullies were usually sampled every month, whereas the sampling locations in grassland and woodland usually varied from month to month. After each drag the ticks on the flannel strips and the leggings were removed using sharp-pointed forceps and stored in 70\% ethyl alcohol in internally labelled, plastic-stoppered glass vials for later identification and quantification.

Sampling commenced in August 1988 and continued in every habitat at the two localities until March 2002, except after heavy rainfall, during a bush fire or upon sighting elephants (Loxodonta africana), African buffaloes (Syncerus caffer) or lions (Panthera leo) in the vicinity.

The identification of the immature stages of ticks, particularly of the lesser-known species, can be a difficult and timeconsuming exercise. The larvae and nymphs of $A$. marmoreum have been described by Theiler and Salisbury (1959), those of D. rhinocerinus by Keirans (1993), of Ha. elliptica by Apanaskevich, Horak and Camicas (2007), of Hy. truncatum by Apanaskevich and Horak (2008), and of the various Rhipicephalus species by Walker, Keirans and Horak (2000).

\section{Results and discussion}

Annual rainfall (June-May) at the Skukuza rest camp averaged $609 \mathrm{~mm}$ over the period of the study, with a range of $275 \mathrm{~mm}-1122 \mathrm{~mm}$ (Figure 1a). Average annual rainfall at the Lower Sabie rest camp, the closest climate station to the Nhlowa Road site, was similar to that at Skukuza. Mean monthly maximum temperatures fluctuated around $33{ }^{\circ} \mathrm{C}$ in mid-summer, while minimums rarely fell below $5{ }^{\circ} \mathrm{C}$ in winter (Figure 1b).

The numbers of all species collected from the vegetation are summarised in Table 1. Four taxa could be identified only to a generic level, including 188 Amblyomma sp. larvae, 104 Haemaphysalis sp. larvae, a single Ixodes sp. nymph and a single Rhipicephalus pravus group larva. Counts of specimens of these four taxa and those of the four major tick species,

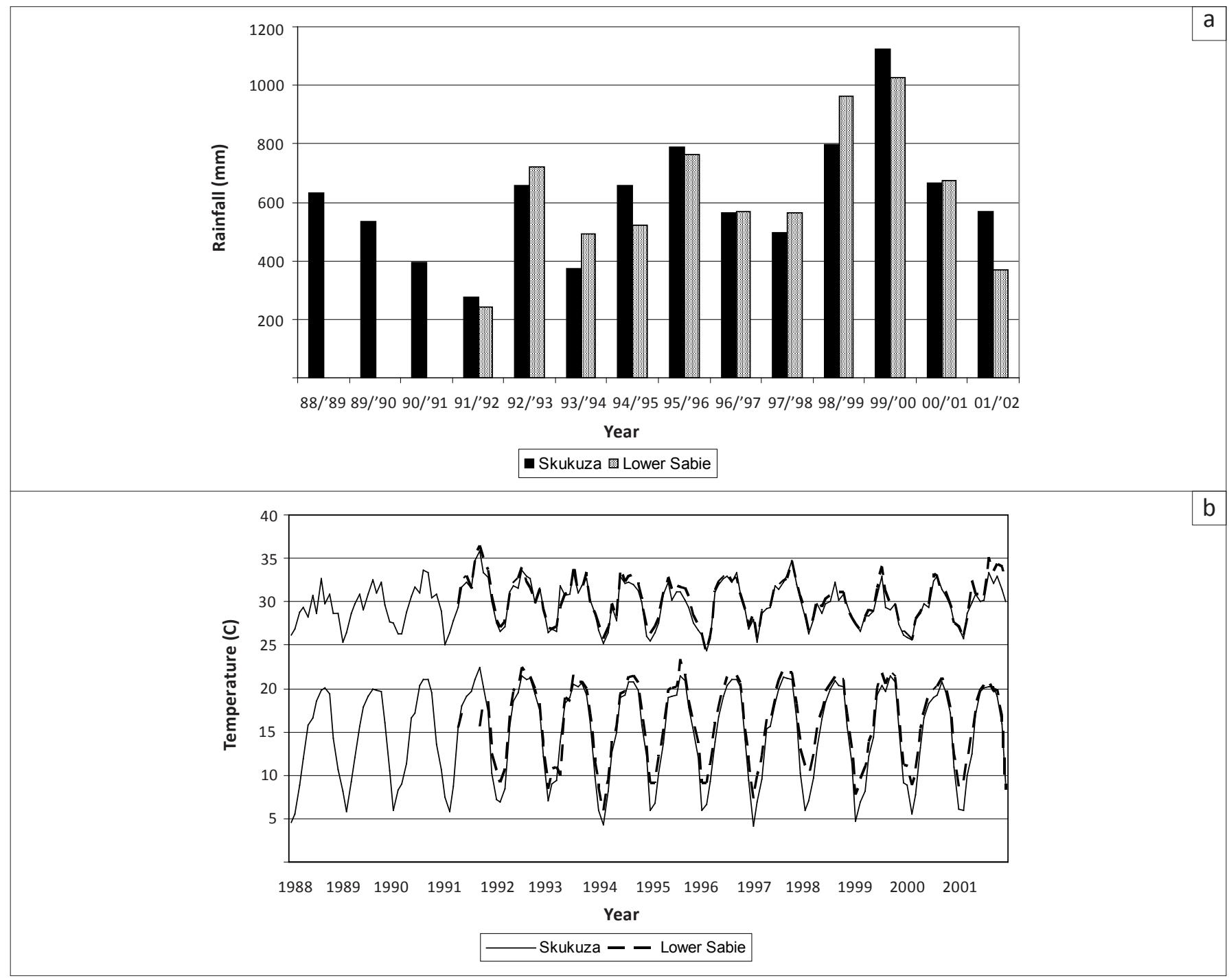

a, weather readings only commenced during 1991 at Nhlowa Road.

FIGURE 1: (a) Annual rainfall (June-May) and (b) mean monthly maximum and minimum temperatures at Skukuza and Lower Sabie ${ }^{a}$, during the study period. 
namely A. hebraeum, R. appendiculatus, $R$. decoloratus and $R$. zambeziensis are listed collectively as 'other species' in the table. Population dynamics of the four major tick species have been discussed in earlier publications (Horak et al. 2011; Spickett et al. 2011). Except for Ha. elliptica, R. simus and $R$. turanicus, of which adults were the most commonly collected stage, larvae were the most commonly collected stage of all these tick species.

\section{Amblyomma marmoreum}

Leopard tortoises (Geochelone pardalis), the largest tortoise species in South Africa (Branch 1998), are the preferred hosts of the adults of $A$. marmoreum and hence it is colloquially known as the South African tortoise tick (Horak et al. 2006a). Adult ticks are rarely found on hosts other than reptiles, but the larvae infest a wide range of hosts, including carnivores, herbivores, hares, birds and reptiles (Horak et al. 2006a).

Amblyomma marmoreum larvae were collected more frequently at Skukuza than at Nhlowa Road $(p<0.001)$ and accounted for $98.8 \%$ of the $A$. marmoreum specimens collected (Table 1). The riverine thickets at Skukuza probably afforded greater protection for younger tortoises against predators and this may explain why larvae were collected more frequently at Skukuza than at Nhlowa Road. The collections were seasonal $(p<0.001)$, with most larvae collected between March and July. There was a definite peak in May at Skukuza but not at Nhlowa Road (Figure 2a). This corresponds to the seasonality of $A$. marmoreum larvae on greater kudus (Tragelaphus strepsiceros), impalas (Aepyceros melampus), scrub hares (Lepus saxatilis) and helmeted guineafowls (Numida meleagris) examined in the KNP (Horak et al. 1991; Horak et al. 1992; Horak et al. 1993; Horak et al. 1995; Horak et al. 2003), and countrywide on leopard tortoises (Horak et al. 2006a).
Although there was considerable year-to-year variability, the numbers of $A$. marmoreum larvae collected each year appeared to decline from 1990 to 2001 (Figure 2b). The size of the collections was not significantly correlated with annual rainfall or rainfall over the activity period (FebruarySeptember). The numbers did not differ significantly among habitats $(p=0.20)$, but there was a trend towards more frequent collections in the gullies than in grassland and woodland (Table 2). The slightly more frequent collections of $A$. marmoreum larvae in gullies could imply that tortoises prefer to browse on the more succulent vegetation usually found there.

\section{Dermacentor rhinocerinus}

Adult D. rhinocerinus are found almost exclusively on black and white rhinoceroses (Diceros bicornis and Ceratotherium simum) (Keirans 1993), of which nearly all in the southern KNP are infested and on which the tick may occur in large numbers (Knapp et al. 1997). Adult ticks quest for their preferred hosts at a height of $1 \mathrm{~m}$ or more on thick-stemmed, tall grass species (Horak, personal observations 2000). They are seldom picked up on flannel strips and only two adults were collected (Table 1). Because adult ticks have a very strong affinity to rhinoceroses they have not been collected from any of the numerous host species we examined in the KNP. It is this affinity that probably makes the operator dragging the flannel strips and the strips themselves unattractive to the ticks.

The rodent hosts of the immature stages have been detected only recently (Horak \& Cohen 2001). In Mthethomusha Nature Reserve (adjacent to the KNP and where there are also white rhinoceroses) three rodent species, namely bushveld gerbils

TABLE 1: Numbers of the less common tick species collected by dragging at the Skukuza and Nhlowa Road sites in the Kruger National Park (August 1988-March 2002).

\begin{tabular}{|c|c|c|c|c|c|}
\hline \multirow[t]{2}{*}{ Species } & \multirow[t]{2}{*}{ Stage } & \multicolumn{2}{|c|}{ Skukuza (Zone 4) } & \multicolumn{2}{|c|}{ Nhlowa Road (Zone 17) } \\
\hline & & $N$ & $\%$ & $N$ & $\%$ \\
\hline \multirow[t]{2}{*}{ Amblyomma marmoreum } & LL & 1604 & 1.27 & 249 & 0.12 \\
\hline & $\mathrm{NN}$ & 6 & $<0.01$ & 3 & $<0.01$ \\
\hline Dermacentor rhinocerinus & LL & 2 & $<0.01$ & 5 & $<0.01$ \\
\hline \multirow[t]{2}{*}{ Haemaphysalis aciculifer } & AA & - & - & 2 & $<0.01$ \\
\hline & $\mathrm{LL}$ & 2 & $<0.01$ & 14 & 0.01 \\
\hline Haemaphysalis hoodi & AA & 1 & $<0.01$ & - & - \\
\hline \multirow[t]{3}{*}{ Haemaphysalis elliptica } & LL & 37 & 0.03 & 23 & 0.01 \\
\hline & $\mathrm{NN}$ & 5 & $<0.01$ & 5 & $<0.01$ \\
\hline & AA & 198 & 0.16 & 363 & 0.17 \\
\hline \multirow[t]{2}{*}{ Hyalomma truncatum } & $\mathrm{LL}$ & 14 & 0.01 & 10 & 0.005 \\
\hline & AA & 3 & $<0.01$ & 2 & $<0.01$ \\
\hline \multirow[t]{3}{*}{ Rhipicephalus evertsi evertsi } & $\mathrm{LL}$ & 1299 & 1.03 & 3921 & 1.85 \\
\hline & $\mathrm{NN}$ & 1 & $<0.01$ & - & - \\
\hline & AA & 1 & $<0.01$ & 2 & $<0.01$ \\
\hline Rhipicephalus maculatus & NN & - & - & 1 & $<0.01$ \\
\hline \multirow[t]{3}{*}{ Rhipicephalus simus } & LL & 83 & 0.07 & 13 & $<0.01$ \\
\hline & $\mathrm{NN}$ & 1 & $<0.01$ & - & - \\
\hline & AA & 323 & 0.26 & 354 & 0.17 \\
\hline \multirow[t]{2}{*}{ Rhipicephalus turanicus } & $\mathrm{LL}$ & 1 & $<0.01$ & 4 & $<0.01$ \\
\hline & AA & 2 & $<0.01$ & 127 & 0.06 \\
\hline All other species & $\mathrm{LL}, \mathrm{NN}, \mathrm{AA}$ & 122227 & 97.16 & 206471 & 97.59 \\
\hline Total & - & 125810 & - & 211569 & - \\
\hline
\end{tabular}

$N$, number of ticks collected; \%, percentage of the number of ticks collected at the site.

LL, larvae; NN, nymphs; AA, adults. 


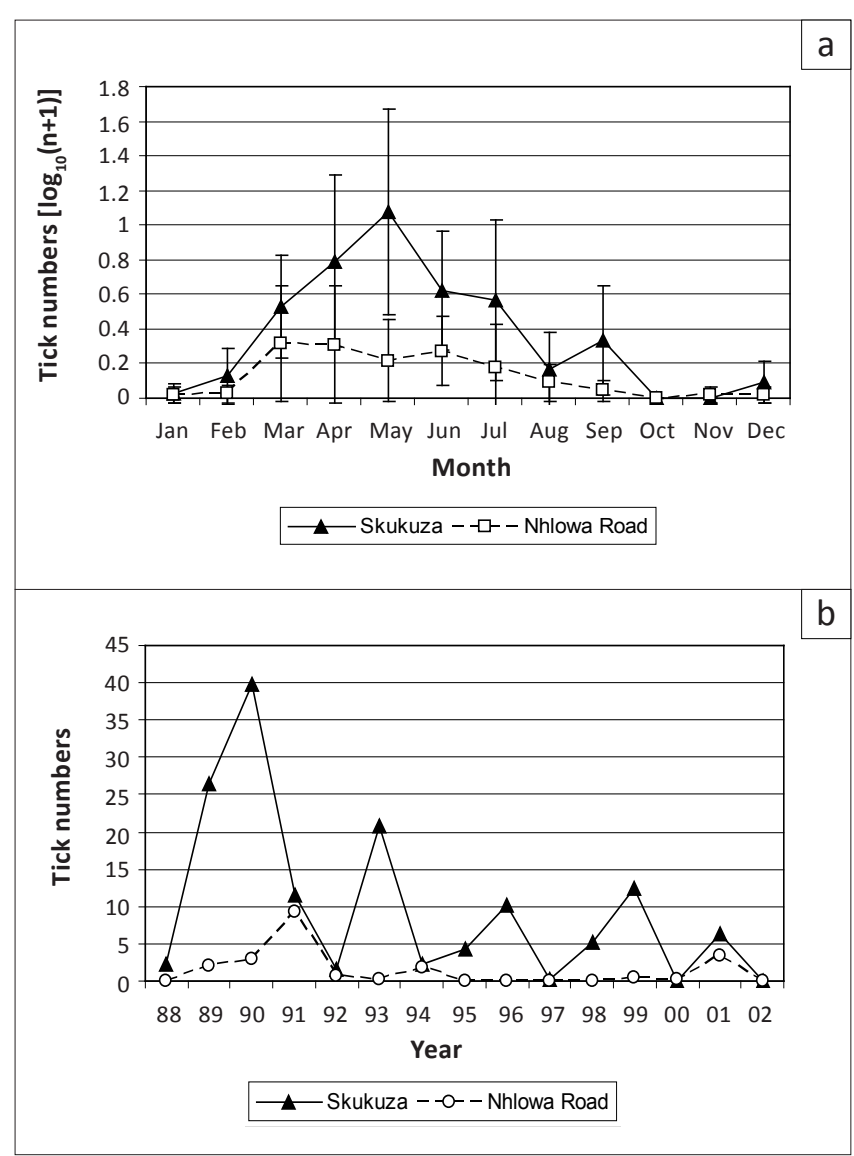

FIGURE 2: (a) Mean collections of Amblyomma marmoreum larvae (mean $\pm 95 \%$ confidence interval) per month and (b) mean monthly collections per year at Nhlowa Road and Skukuza.

(Tatera leucogaster), red veld rats (Aethomys chrysophilus) and Natal multimammate mice (Mastomys natalensis) were found infested with the immature stages of $D$. rhinocerinus (Horak \& Cohen 2001). The small size of these animals implies that the immature stages of $D$. rhinocerinus quest for hosts from the soil surface rather than the vegetation, and only seven larvae were collected from the flannel strips (Table 1). No bushveld gerbils or red veld rats examined in the KNP were infested (Braack et al. 1996).

\section{Haemaphysalis elliptica}

Haemaphysalis elliptica is an old taxon - originally described by Koch around the Cape of Good Hope in the nineteenth century - and has recently been reinstated as a valid species (Apanaskevich et al. 2007). All reports of Ha. leachi in South
Africa from before 2007 are, in fact, incorrect and should actually refer to Ha. elliptica, as Ha. leachi does not occur in this country (Apanaskevich et al. 2007).

Adult ticks were the most commonly collected stage of Ha. elliptica. In the KNP adult ticks have most often been collected from the larger felids, such as lions, leopards (Panthera pardus), cheetahs (Acinomyx jubatus) and African civets (Civettictis civetta). They have also been recovered from African wild cats (Felis silvestris) and feral cats (Felis cattus), black-backed jackals (Canis mesomelas), wild dogs (Lycaon pictus) and spotted hyaenas (Crocuta crocuta) (Horak et al. 1987; Horak et al. 2000a). The immature stages are usually found on rodents (Braack et al. 1996; Horak, Fourie \& Braack 2005), but small numbers may also infest carnivores, scrub hares and helmeted guineafowls (Horak et al. 1987; Horak et al. 1991; Horak et al. 1993; Horak et al. 1995; Horak et al. 2000a). Very few larvae or nymphs were collected from the vegetation (Table 1). However, as their preferred hosts are rodents, they probably quest for these from the soil surface and do not attach to flannel strips dragged over the vegetation.

Haemaphysalis elliptica adults were more commonly collected at Nhlowa Road than at Skukuza $(p=0.001)$. Landscape Zone 17 is at the centre of lion activity in the KNP (Gertenbach 1983), which may account for the greater number of adult ticks in this area. There was a significant difference between the numbers of adults collected over years $(p<0.001)$. Some were collected from 1988 to 1990, but few were collected from 1991 to 1993 . The numbers then increased, with a marked peak in 2000 (Figure 3a). The patterns were similar at both sites, but there was a significant year-by-site interaction $(p<0.001)$, because more were collected at Skukuza in 1988 and 1989 while more were collected at Nhlowa Road in the other years. The collections of adult ticks were correlated with annual rainfall of the preceding year at both sites $(r>0.67 ; p<0.01)$. A significant correlation with rainfall 2 years before was also observed at Skukuza ( $p=0.64 ; p<0.05)$, and a positive but non-significant correlation with rainfall observed at Nhlowa road $(p=0.48 ; p<0.2)$. The dramatic increase in numbers in 1999 and 2000 followed 2 years of above-average rainfall in 1998 and 1999. Following a rodent explosion in 1993 (Horak, Spickett \& Braack 2000b), after above-average annual rainfall in 1992, numbers peaked slightly at Nhlowa Road in 1994 and 1995. The increase in numbers of Ha. elliptica adults around the turn of the century was probably also associated

TABLE 2: Mean monthly tick collections $\left[\log _{10}(n+1)\right]$ by habitat.

\begin{tabular}{|c|c|c|c|c|c|c|c|c|c|c|}
\hline \multirow[t]{2}{*}{ Species } & \multirow[t]{2}{*}{ Stage } & \multicolumn{3}{|c|}{ Combined } & \multicolumn{3}{|c|}{ Skukuza (Zone 4) } & \multicolumn{3}{|c|}{ Nhlowa Road (Zone 17) } \\
\hline & & grassland & gully & woodland & grassland & gully & woodland & grassland & gully & woodland \\
\hline Amblyomma marmoreum & $\mathrm{LL}^{1}$ & 0.164 & 0.225 & 0.146 & 0.281 & 0.327 & 0.233 & 0.054 & 0.128 & 0.064 \\
\hline Haemaphysalis elliptica & $\mathrm{AA}$ & $0.102^{a, b}$ & $0.139^{\mathrm{a}}$ & $0.088^{b}$ & 0.094 & 0.101 & 0.069 & $0.109^{\mathrm{a}}$ & 0.174 & $0.106^{\mathrm{a}}$ \\
\hline Rhipicephalus evertsi evertsi & $\mathrm{LL}$ & $0.468^{\mathrm{a}}$ & 0.244 & $0.454^{\mathrm{a}}$ & 0.253 & 0.171 & 0.322 & $0.669^{\mathrm{a}}$ & 0.313 & $0.578^{a}$ \\
\hline Rhipicephalus simus & $A A^{2}$ & $0.076^{\mathrm{a}}$ & $0.240^{c}$ & $0.145^{b}$ & $0.105^{\mathrm{a}}$ & $0.224^{\mathrm{b}}$ & $0.179^{\mathrm{a}, \mathrm{b}}$ & $0.049^{\mathrm{a}}$ & 0.255 & $0.115^{\mathrm{a}}$ \\
\hline Rhipicephalus turanicus & $A A^{3}$ & - & - & - & - & - & - & $0.096^{\mathrm{a}, \mathrm{b}}$ & $0.181^{\mathrm{a}}$ & $0.034^{b}$ \\
\hline
\end{tabular}

Habitats with the same superscripted letter within a site are not significantly different $(p<0.05)$.

Numbered superscripts denote the period of collection: ${ }^{1}$, Mar-Sep; ${ }^{2}$, Oct-Jun; ${ }^{3}$, Jan-Jun.

LL, larvae; AA, adults. 
with an increase in rodent populations during a period of above-average rainfall.

According to the time series assessment, the seasonality of Ha. elliptica adults was not statistically significant, probably because of the small numbers collected in most years. However, an ANOVA showed a significant difference between months $(p<0.001)$, with the largest numbers collected in late summer and autumn (February-June) and the smallest numbers in spring (September-November) (Figure 3b). A similar pattern was observed at both sites. There are no data regarding the seasonality of adult Ha. elliptica on carnivores in the KNP, but in north-eastern KwaZulu-Natal, south-east of the KNP, adult ticks on dogs in rural communities were found mostly from January to March or April (Horak, Emslie \& Spickett 2001).

Haemaphysalis elliptica larvae were more commonly collected at Skukuza than at Nhlowa Road. Most larvae were collected in 1989 and 1990, and only sporadically thereafter. The largest numbers were collected in September and November, and only two of the 60 were collected between January and April. Nymphs were collected sporadically in the early 1990s and again towards the turn of the century. Eight of the 10 nymphs were collected between July and October. The SeptemberNovember and July-October peaks for collections of $\mathrm{Ha}$. elliptica larvae and nymphs, respectively, correspond to the seasonal peaks in Ha. elliptica/spinulosa larval and nymphal infestations on red veld rats in the southern KNP (Braack et al. 1996).

As shown in Table 2, the largest numbers of Ha. elliptica adults were collected in the gullies, while fewest were collected in woodland $(p<0.01)$. This pattern was consistent over months and at both sites. However, there was a significant difference between years $(p=0.02)$, with the largest numbers collected in the gullies until the late 1990s (Figure 3c) followed by more frequent collections in grassland and woodland. Eight of the ten nymphs were collected in the gullies.

Tall grasslands appear to support a higher diversity of small mammal populations (Monadjem 1997), but many of the rodent hosts of the immature stages of $\mathrm{Ha}$. elliptica prefer sheltered, rocky areas (Skinner \& Smithers 1990). During periods of below-average rainfall, when grass swards were shorter and ground cover was reduced, gullies were probably the preferred habitat of many of the rodent hosts. Around the turn of the century the majority of Ha. elliptica adults were collected in grassland and woodland. Denser ground cover and taller grass swards following a period of higher rainfall would have provided a more suitable habitat for many rodent species, and an increase in rodent populations would have led to an expansion of habitat use. Thus, the population dynamics and habitat distribution of questing $\mathrm{Ha}$. elliptica are probably determined by the effects of rainfall on the populations of rodent hosts of the immature stages, rather than the carnivore hosts of the adults.

\section{Hyalomma truncatum}

Although only 24 larvae and five adult Hy. truncatum were collected from the vegetation (Table 1), these low numbers should not be regarded as a reflection of actual abundance of this tick in the KNP. During the first 6 years of this survey, five scrub hares were examined monthly around Skukuza, and the 360 examinations during this time yielded a total of 36647 larvae and 9896 nymphs of this two-host tick (Horak
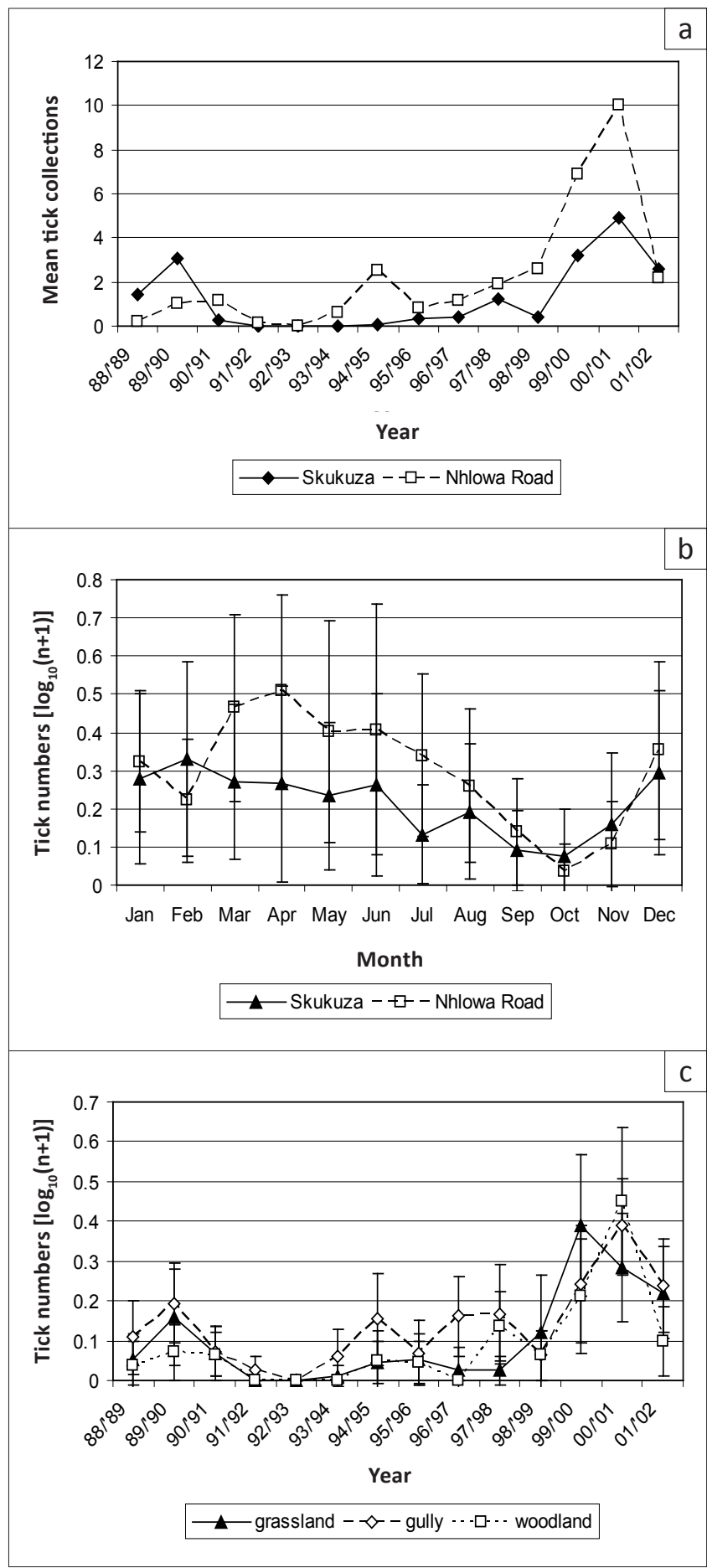

FIGURE 3: (a) Mean monthly collections of Haemaphysalis elliptica adults from each site per year, (b) mean collections ( $\pm 95 \%$ confidence interval) per month from each site and (c) mean collections ( $\pm 95 \%$ confidence interval) from each habitat per year. 
et al. 1993; Horak et al. 1995). Adult Hy. truncatum have been collected from the large browsers and grazers in the $\mathrm{KNP}$, including giraffes (Giraffa camelopardalis), Burchell's zebras (Equus burchellii), elands, (Taurotragus oryx), white rhinoceroses and kudus, as well as warthogs (Phacochoerus africanus) (Horak, De Vos \& De Klerk 1984; Horak et al. 1988; Horak et al. 1992; Horak, Golezardy \& Uys 2007; Knapp et al. 1997). The discrepancy between the numbers collected by dragging and the numbers on scrub hares strongly suggests that Hy. truncatum larvae quest for hosts from the soil surface. The adults definitely quest for hosts from the soil surface and can readily be seen scuttling along the ground towards any large potential host.

\section{Rhipicephalus evertsi evertsi}

Rhipicephalus evertsi evertsi is a two-host tick that infests a wide range of host species (Walker et al. 2000). In the KNP, Burchell's zebras and giraffes appear to be preferred hosts for all stages (Horak et al. 1984; Horak et al. 2007), while impalas and scrub hares are important hosts for the immature stages (Horak et al. 1993; Horak et al. 1995; Horak et al. 2003). Larvae were most commonly collected during dragging (Table 1) and, theoretically, only larvae and adults should quest for hosts. The single nymph that was collected had probably become dislodged just before or after moulting and was questing for a host. Very few adults were collected, probably because they quest for hosts from the soil surface or, like the adults of many species, they do not attach to flannel strips.

In previous drag-sampling studies in Landscape Zones 4 and 17 there was no evidence of seasonality in the numbers of questing R. evertsi evertsi larvae collected (Spickett et al. 1992; Horak et al. 2006b). The present study, however, showed significant periodicity at both sites $(p<0.001)$. At Nhlowa Road there were two annual peaks (November-February and June-July), whereas at Skukuza, there was only a single peak (November-December) with a nadir between May and June (Figure 4a). Based on the development times seen in the laboratory, $R$. evertsi evertsi can complete more than one life cycle annually at the prevailing temperatures in the KNP (Horak et al. 2003). At Nhlowa Road the summer and winter peaks correspond to those observed on Burchell's zebras (Horak et al. 1984), suggesting that the seasonal pattern was related to the pattern of zebra migration. At Skukuza, the late spring peak and late autumn nadir differed not only from the pattern observed in other drag-sampling studies but also from that observed on impalas and scrub hares in this landscape zone (Horak et al. 1993; Horak et al. 2003). The reasons for the differences between the seasonal patterns observed in the present study and previous studies are unknown. They may be related to seasonal differences in habitat use by ungulates within Landscape Zone 4, or they may be because of the relatively short duration of the sampling periods (1-4 years) in the earlier studies. In the present study there was considerable variability among years and the general seasonal pattern was seen only over the longer time period.

The numbers of $R$. evertsi evertsi larvae collected differed significantly among years $(p<0.001)$ and there was

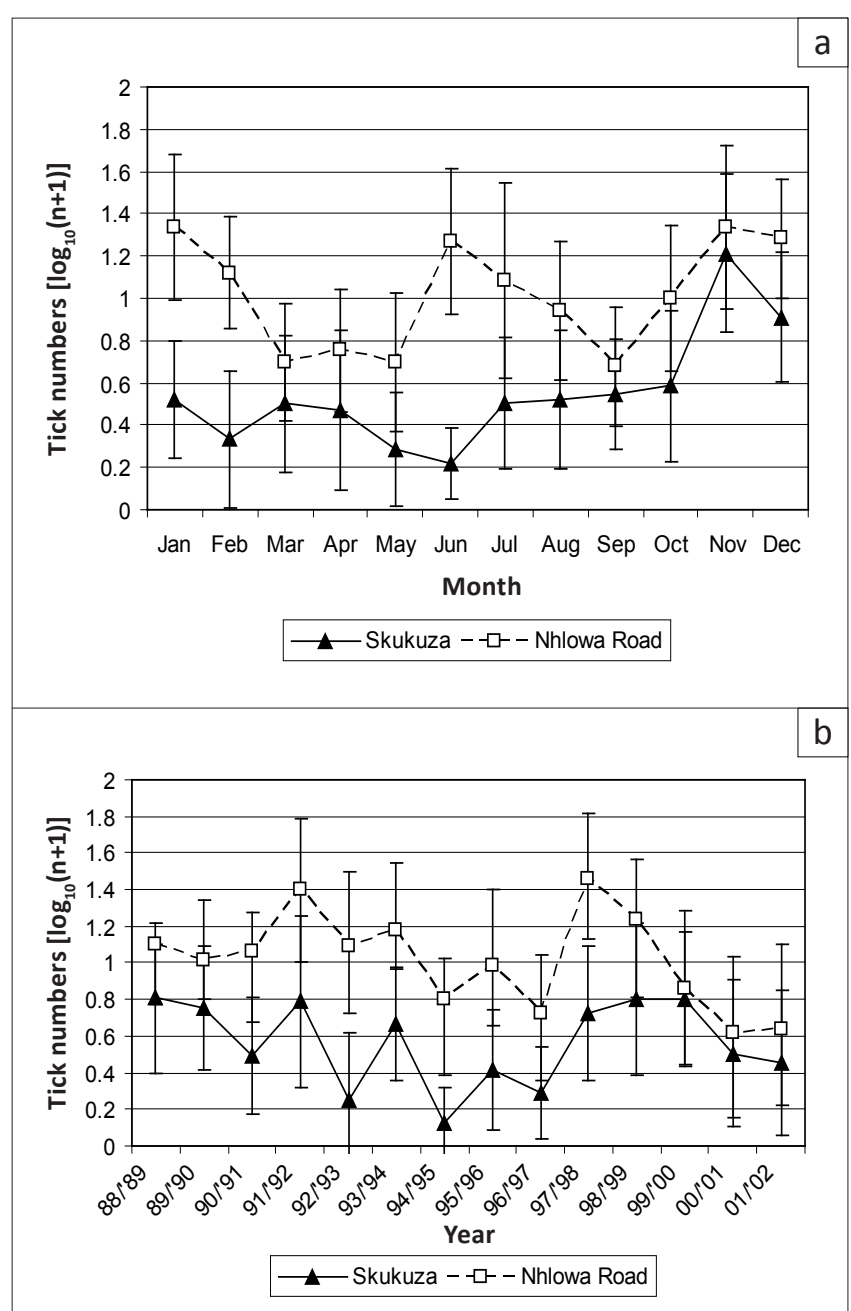

FIGURE 4: Mean collections ( $\pm 95 \%$ confidence interval) of Rhipicephalus evertsi evertsi larvae (a) by month and (b) by year at the two sites.

a significant year-by-site interaction $(p=0.028)$, with proportionally greater changes at Skukuza than at Nhlowa Road. However, the trends were similar at both sites, with peaks in the early 1990s, a decline through the mid-1990s, and subsequent increases in the late 1990s. Numbers declined in 2000 (Figure 4b). The numbers were not significantly correlated with seasonal rainfall at either site. The apparent differences in the annual trends at the two sites may be related to differences in the host communities. The populations of the larger ungulates at Nhlowa Road, such as zebras and giraffes, appear to be less sensitive to changes in rainfall (Ogutu \& Owen-Smith 2005) than the populations of smaller ungulates, such as impalas, at Skukuza.

Larvae were more commonly collected at Nhlowa Road than at Skukuza $(p<0.001)$ and there was a significant habitat-bysite interaction $(p=0.002)$. At Nhlowa Road, larvae were least frequently collected in the gullies and most commonly in the grassland (Table 2), probably because of the large numbers of zebras and other grazers at this locality. At Skukuza, $R$. evertsi evertsi larvae were most commonly collected in the woodland, probably because of the presence of large numbers of impalas and other browsers, but the difference among habitats was not statistically significant $(p>0.1)$. The differences among habitats were not significant among months or years $(p>0.4)$. 


\section{Rhipicephalus simus}

Adults were the most commonly collected stage of $R$. simus. The preferred hosts of adult $R$. simus are large ruminants, such as African buffaloes, and monogastric animals, such as large carnivores, warthogs, zebras and rhinoceroses (Walker et al. 2000). Large numbers of $R$. simus adults have been collected from lions, leopards, warthogs, Burchell's zebras and white rhinoceroses in the KNP (Horak et al. 1984; Horak et al. 1988; Horak et al. 2000a; Knapp et al. 1997).

The collections of $R$. simus were seasonal, with a peak between February and March and a nadir between August and September (Figure 5a). The numbers did not differ significantly between the two sites $(p=0.2)$ and the seasonal patterns were similar. The peak in adult numbers corresponds with that on Burchell's zebras and warthogs in the KNP (Horak et al. 1984; Horak et al. 1988) and on warthogs in Swaziland in a Sclerocarya caffra - Acacia nigrescens savanna (Gallivan \& Surgeoner 1995).

There was a significant difference between the numbers of $R$. simus adults collected over the years $(p<0.001)$. Numbers declined from 1988 to 1991, then increased again in 1994, followed by a peak in 2000 (Figure $5 b$ ). The trends differed significantly between the two sites $(p<0.001)$. At Skukuza, numbers tended to be higher between 1988 and 1989 than from 1997 to 2000 . However, at Nhlowa Road the numbers of R. simus adults were higher from 1993 to 1995, with a marked peak in 1994.

The numbers of adult $R$. simus collected at Skukuza were significantly correlated with annual rainfall during the 2 previous years $(p<0.05)$. At Nhlowa Road, the numbers were significantly correlated with rainfall 2 years before $(p=0.05)$, but not with that of the preceding year. The decline in numbers in the early 1990s corresponded to a period of decreasing annual rainfall and to a marked decline in the warthog population in the KNP (Ogutu \& Owen-Smith 2005). The decline in annual rainfall probably also caused a decline in the populations of rodents, which are the preferred hosts of the immature stages of this tick (Braack et al. 1996; Horak et al. 2005; Norval \& Mason 1981; Petney et al. 2004).

Following a period of above-average rainfall in 1992, there was an eruption of rodent populations in 1993 (Horak et al. 2000b) that may have accounted for the large number of adult $R$. simus collected at Nhlowa Road during 1994. As with the adults of Ha. elliptica, the increase in the numbers of $R$. simus adults around the turn of the century was probably associated with an increase in rodent populations during a period of above-average rainfall.

As shown in Table 2, adult $R$. simus were most commonly collected in the gullies and least frequently in the grassland $(p<0.001)$. There was a significant difference in the habitat distribution between the two sites $(p=0.03)$. At Skukuza, $48.3 \%$ of the ticks were collected in the gullies and $16.4 \%$ in grassland, whereas at Nhlowa Road, $69.2 \%$ were collected in the gullies and only $7.6 \%$ in grassland. Habitat distribution

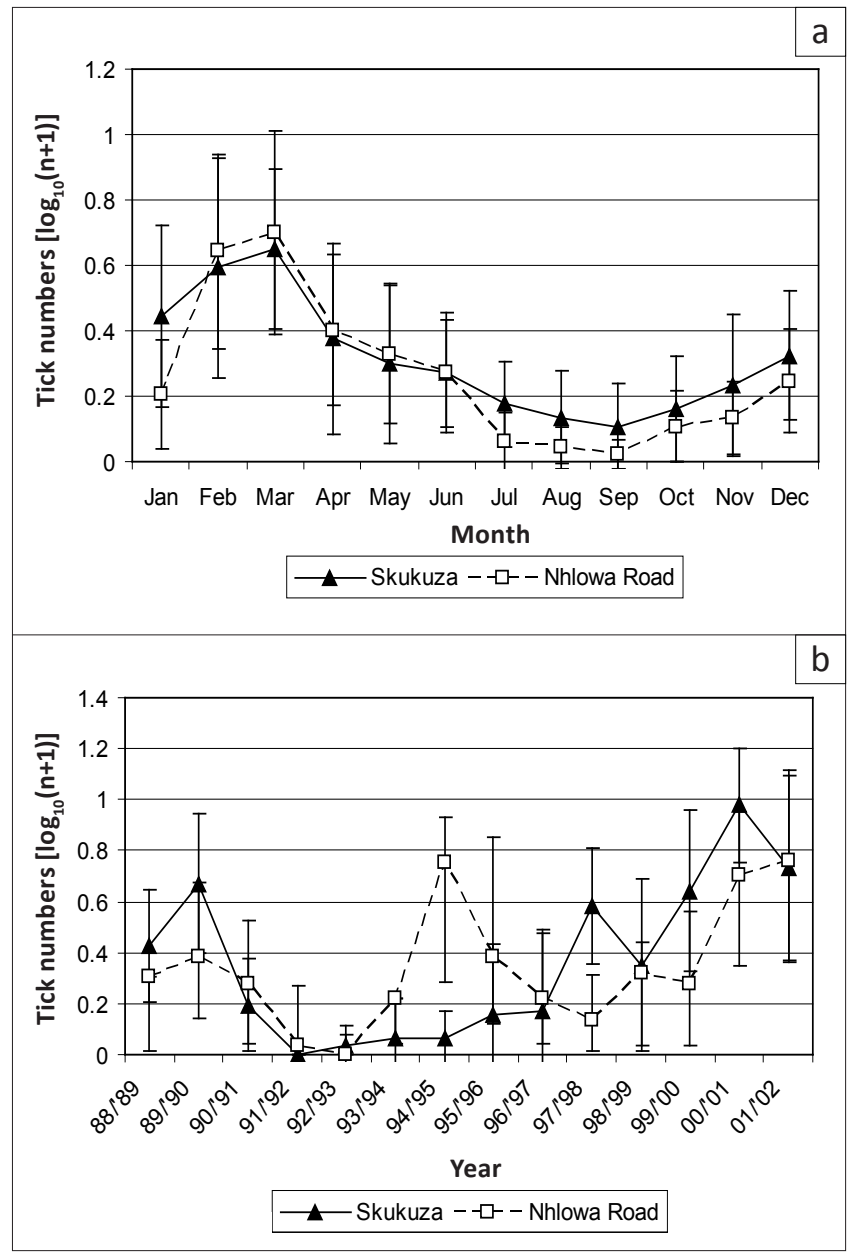

FIGURE 5: Mean collections ( $\pm 95 \%$ confidence interval) of Rhipicephalus simus adults (a) by month and (b) by year at Nhlowa Road and Skukuza.

differed significantly among months $(p=0.025)$, with the most pronounced difference during February and March, the period of peak activity. There was also a marginally significant difference in habitat distribution among years $(p=0.1)$, with highest numbers in the gullies; however, in 2000 the numbers were marginally higher in woodland. As in the case of Ha. elliptica, the habitat distribution probably corresponds to the pattern of habitat use by the hosts of the immature stages.

Rhipicephalus simus larvae were more frequently collected at Skukuza than at Nhlowa Road. Almost half (45.8\%) were collected in 1989, while the second largest collection (14.6\%) was made in 2001. Other collections were sporadic. At Skukuza, most $R$. simus larvae were collected from January to June, but at Nhlowa Road most were collected from June to November. At Skukuza, more larvae were collected in the gullies than in grassland, whereas at Nhlowa Road, most larvae were collected in woodland.

\section{Rhipicephalus turanicus}

Adult $R$. turanicus have been collected from lions, leopards, cheetahs, African wild dogs, feral cats and scrub hares in the $\mathrm{KNP}$, but none of the animals were heavily infested (Horak et al. 1993; Horak et al. 1995; Horak et al. 2000a). No immature stages have been collected from animal hosts within the 
KNP or adjacent nature reserves. Scrub hares examined on farms around Hluhluwe in north-eastern KwaZulu-Natal were infested with all stages of $R$. turanicus (Horak et al. 1995) and crested francolins (Francolinus sephaena) on a farm in Limpopo were infested with larvae (Uys \& Horak 2005). Adult ticks were also common on dogs in Maputo Province, Mozambique, adjacent to the KNP (Neves, Afonso \& Horak 2004).

Rhipicephalus turanicus was most commonly collected at Nhlowa Road (97.8\%) and adults were the most commonly collected stage (Table 1). As mentioned before, Landscape Zone 17 is at the centre of lion distribution within the KNP (Gertenbach 1983) and the herds of large grazers would support populations of other carnivores. Collections were seasonal $(p<0.001)$, with a peak between February and March (Figure 6a). There were significant differences between the numbers collected among years $(p=0.002)$, with peaks in 1991, 1994, 1995, 1999, 2001 and 2002 (Figure 6b). The numbers of $R$. turanicus adults were not correlated with rainfall and, as shown in Table 2, ticks of this stage were collected in the gullies more often than in woodland $(p<0.001)$. This pattern was consistent among years and months.

There was a strong correlation $(r=0.7 ; p=0.009)$ between the numbers of adult $R$. simus and adult $R$. turanicus collected annually at Nhlowa Road. The year-to-year patterns of the two species were similar and both species were most commonly collected in the gullies. However, woodland yielded the fewest $R$. turanicus adults, whereas the grassland yielded the fewest $R$. simus adults. The distribution of adult $R$. turanicus among habitats and year-to-year collection patterns were also similar to those of adult Ha. elliptica at the Nhlowa Road site.

\section{Conclusion}

In order to determine the population dynamics of free-living ixodid ticks, questing ticks were collected monthly for 164 months from the vegetation at two localities in the KNP. Of the collected species, 14 could be identified to specific level. Larvae of $A$. marmoreum and $R$. evertsi evertsi, and adults of Ha. elliptica, R. simus and R. turanicus were collected in sufficient numbers to conclude that they quest for hosts from the vegetation. The host-seeking strategies of their remaining developmental stages and those of the tick species collected only in small numbers still need to be investigated.

The value of long term sampling at more than one locality and within various habitats at each locality yielded several answers and posed a number of questions. Should more samples be taken within the predominant habitat at a locality, for example in the thickets and woodlands of a thicket locality and in the grasslands of a savanna locality, to obtain more accurate results pertaining to an entire locality? What are the reasons for markedly more numerous questing ticks in a treed savanna locality compared with a locality composed largely of thickets? What value can be added by simultaneously sampling the major host species within a
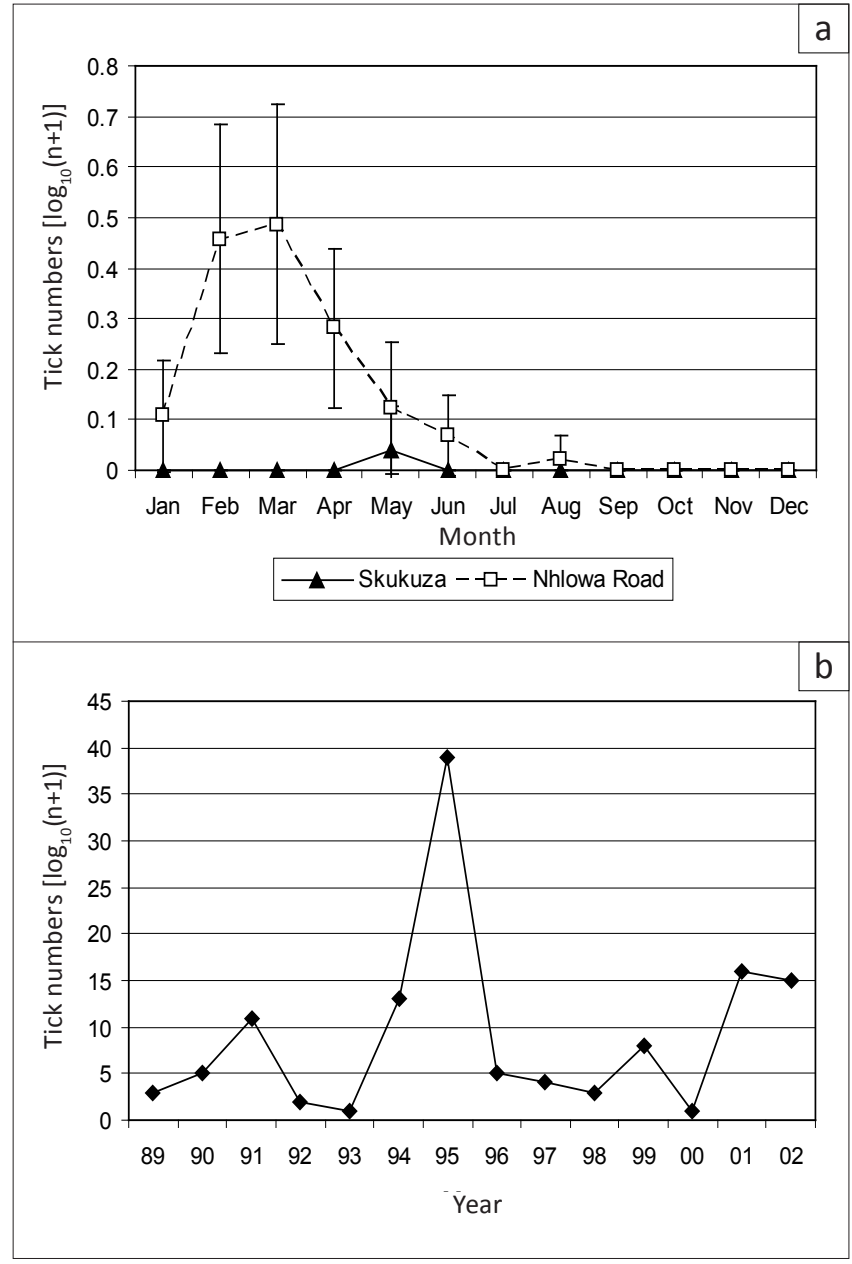

FIGURE 6: (a) Mean collections ( $\pm 95 \%$ confidence interval) of Rhipicephalus turanicus adults by month at the two sites and (b) total collections by year at Nhlowa Road.

study site for ticks and determining host densities and daily and seasonal movements?

Finally, logistical challenges to what can be achieved in the field in a large nature reserve need to be considered, for example (1) the dangers posed to field workers by large predators, African buffaloes, rhinoceroses and elephants, (2) the number of drag samples that can be accomplished in a day to ensure reasonable homogeneity, as the total length of the drags placed end to end covered a distance of $2250 \mathrm{~m}$ at each locality, and (3) the number of people, besides an armed ranger, needed to collect, within a reasonable time frame, the thousands of ticks sometimes collected in a single drag.

\section{Acknowledgements}

We are indebted to the South African National Parks (SANParks) for placing their staff and facilities in the KNP at our disposal. We gratefully acknowledge the assistance of Dr Leo Braack and Mr André Potgieter with arranging the logistics for the collections. A number of nature conservation and veterinary students assisted with many of the field collections. Our special thanks, however, are reserved for the SANParks staff at Skukuza, who were our armed guards and assisted with the collection of the many thousands of ticks from the flannel strips. The research was funded by 
the University of Pretoria (Faculty of Veterinary Science), SANParks, Bayer Animal Health, the University of the Free State and the National Research Foundation.

\section{References}

Acocks, J.P.H., 1988, Veld types of South Africa with accompanying veld type map, 3rd edn., Department of Agriculture and Water Supply, Pretoria.

Apanaskevich, D.A., Horak, I.G. \& Camicas, J-L, 2007, 'Redescription of Haemaphysalis (Rhipistoma) elliptica (Koch, 1844), an old taxon of the Haemaphysalis (Rhipistoma) leachi group from East and southern Africa, and of Haemaphysalis (Rhipistoma) leachi (Audouin, 1826) (Acarina, Ixodidae)', Onderstepoort Journal of Veterinary Research 74, 181-208. PMid:17933361

Apanaskevich, D.A. \& Horak, I.G., 2008, 'The genus Hyalomma. VI. Systematics of $H$. (Euhyalomma) truncatum and the closely related species, $H$. (E.) albiparmatum and $H$. (E.) nitidum (Acari, Ixodidae)', Experimental and Applied Acarology 44, 115-136. doi:10.1007/s10493-008-9136-z, PMid:18306046

Braack, L.E.O., Horak, I.G., Jordaan, L.C., Segerman, J. \& Louw, J.P., 1996, 'The comparative host status of red veld rats (Aethomys chrysophilus) and bushveld gerbils (Tatera leucogaster) for epifaunal arthropods in the southern Kruger National Park, South Africa', Onderstepoort Journal of Veterinary Research 63, 149-158. PMid:8856764

Branch, W.R., 1998, Field guide to snakes and other reptiles of southern Africa, Struik, Cape Town.

Gallivan, G.J. \& Surgeoner, G.A., 1995, 'Ixodid ticks and other ectoparasites of wild ungulates in Swaziland: regional, host and seasonal patterns', South African Journal of Zoology 30, 169-177.

Gertenbach, W.P.D., 1983, 'Landscapes of the Kruger National Park', Koedoe 26, 9-121.

Horak, I.G., De Vos, V. \& De Klerk, B.D., 1984, 'Parasites of domestic and wild animals in South Africa. XVII. Arthropod parasites of Burchell's zebra, Equus burchelli, in the eastern Transvaal Lowveld', Onderstepoort Journal of Veterinary Research 51 145-154. PMid:6493729

Horak, I.G., Jacot Guillarmod, A., Moolman, L.C. \& De Vos, V., 1987, 'Parasites of domestic and wild animals in South Africa. XXII. Ixodid ticks on domestic dogs and on wild carnivores', Onderstepoort Journal of Veterinary Research 54, 573-580. PMid:3444612

Horak, I.G., Boomker, J., De Vos, V. \& Potgieter, F.T., 1988, 'Parasites of domestic and wild animals in South Africa. XXIII. Helminth and arthropod parasites of warthogs, Phacochoerus aethiopicus, in the eastern Transvaal Lowveld', Onderstepoor Journal of Veterinary Research 55, 145-152. PMid:3194114

Horak, I.G., Spickett, A.M., Braack, L.E.O. \& Williams, E.J., 1991, 'Parasites of domestic and wild animals in South Africa. XXVII. Ticks on helmeted guineafowls in the eastern Cape Province and eastern Transvaal Lowveld', Onderstepoort Journal of Veterinary Research 58, 137-143. PMid:1923375

Horak, I.G., Boomker, J., Spickett, A.M. \& De Vos, V., 1992, 'Parasites of domestic and wild animals in South Africa. XXX. Ectoparasites of kudus in the eastern Transvaal Lowveld and the eastern Cape Province', Onderstepoort Journal of Veterinary Research 59, 259-273. PMid:1297956

Horak, I.G., Spickett, A.M., Braack, L.E.O. \& Penzhorn, B.L., 1993, 'Parasites of domestic and wild animals in South Africa. XXXII. Ixodid ticks on scrub hares in the Transvaal', and wild animals in South Africa. XXXII. Ixodid ticks on scrub hares in the Trans
Onderstepoort Journal of Veterinary Research 60, 163-174. PMid:7970571

Horak, I.G., Spickett, A.M., Braack, L.E.O., Penzhorn, B.L., Bagnall, R.J. \& Uys, A.C. 1995, 'Parasites of domestic and wild animals in South Africa. XXXIII. Ixodid ticks on scrub hares in the north-eastern regions of Northern and Eastern Transvaal and of KwaZulu-Natal', Onderstepoort Journal of Veterinary Research 62, 123-131. PMid:8600436

Horak, I.G., Braack, L.E.O., Fourie, L.J. \& Walker, J.B., 2000a, 'Parasites of domestic and wild animals in South Africa. XXXVIII. Ixodid ticks collected from 23 wild carnivore species', Onderstepoort Journal of Veterinary Research 67, 239-250. PMid:11206391

Horak, I.G., Spickett, A.M. \& Braack, L.E.O., 2000b, 'Fluctuations in the abundance of Boophilus decoloratus and three Rhipicephalus species on vegetation during eleven consecutive years', in M. Kazimírová, M. Labuda \& P.A. Nuttal (eds.), Proceedings of the 3rd International Conference on Ticks and Tick-borne Pathogens, into the 21st century, Bratislava, Slovakia, 30 August-03 September, 1999, pp. 247-251.
Horak, I.G. \& Cohen, M., 2001, 'Hosts of the immature stages of the rhinoceros tick, Dermacentor rhinocerinus (Acari, Ixodidae)', Onderstepoort Journal of Veterinary Research 68, 75-77. PMid:11403434

Horak, I.G., Emslie, F.R. \& Spickett, A.M., 2001, 'Parasites of domestic and wild animals in South Africa. XL. Ticks on dogs belonging to people in rural communities and carnivore ticks on the vegetation', Onderstepoort Journal of Veterinary Research 68 , 135-141. PMid:11585091

Horak, I.G., Gallivan, G.J., Braack, L.E.O., Boomker, J. \& De Vos, V., 2003, 'Parasites of domestic and wild animals in South Africa. XLI. Arthropod parasites of impalas (Aepyceros melampus) in the Kruger National Park', Onderstepoort Journal of Veterinary Research 70, 131-163. PMid:12967174

Horak, I.G., Fourie, L.J. \& Braack, L.E.O., 2005, 'Small mammals as hosts of immature ticks', Onderstepoort Journal of Veterinary Research 72, 255-261. PMid:16300195

Horak, I.G., Mckay, I.J., Heyne, H. \& Spickett, A.M., 2006a, 'Hosts, seasonality and geographic distribution of the South African tortoise tick, Amblyomma marmoreum', Onderstepoort Journal of Veterinary Research 73, 13-25. PMid:16715875

Horak, I.G., Gallivan, J., Spickett, A.M. \& Potgieter, A.L.F., 2006b, 'Effect of burning on the numbers of questing ticks collected by dragging', Onderstepoort Journal of Veterinary Research 73, 163-174. PMid:17058438

Horak, I.G., Golezardy, H. \& Uys, A.C., 2007, 'Ticks associated with the three largest wild ruminant species in southern Africa', Onderstepoort Journal of Veterinary wild ruminant species in southern Africas
Research 74, 231-242. PMid:17933365

Horak, I.G., Gallivan, G.J. \& Spickett, A.M., 2011, 'The dynamics of questing ticks collected for 164 consecutive months off the vegetation of two landscape zones in the Kruger National Park (1988-2002). I. Total ticks, Amblyomma hebraeum and Rhipicephalus decoloratus', Onderstepoort Journal of Veterinary Research 78(1), Art. Rhipicephalus decoloratus', Onderstepoort
$\# 32,10$ pages, doi:10.4102/ojvr.v78i1.32

Keirans, J.E., 1993, 'Dermacentor rhinocerinus (Denny, 1843) (Acari, Ixodida, Ixodidae), redescription of the male, female and nymph and first description of the larva', Onderstepoort Journal of Veterinary Research 60, 59-68. PMid:8332318

Knapp, S.E., Krecek, R.C., Horak, I.G. \& Penzhorn, B.L., 1997, 'Helminths and arthropods of black and white rhinoceroses in southern Africa', Journal of Wildlife Diseases 33, 492-502. PMid:9249695

Monadjem, A., 1997, 'Habitat preferences and biomasses of small mammals in Swaziland', African Journal of Ecology 35, 64-72. doi:10.1111/j.13652028.1997.042-89042.x

Neves, L., Afonso, S. \& Horak, I.G., 2004, 'Ixodid ticks on dogs in and around Maputo and elsewhere in Mozambique', Onderstepoort Journal of Veterinary Research 71, 279-283. PMid:15732454

Norval, R.A.I. \& Mason, C.A., 1981, 'The ticks of Zimbabwe. II. The life cycle, distribution and hosts of Rhipicephalus simus Koch, 1844', Zimbabwe Veterinary Journal 12, 2-9.

Ogutu, J.O. \& Owen-Smith, N., 2005, 'Oscillations in large mammal populations: are they related to predation or rainfall?', African Journal of Ecology 43, 332-339. doi:10.1111/j.1365-2028.2005.00587.x

Petney, T.N., Horak, I.G., Howell, D.J. \& Meyer, S., 2004, 'Striped mice, Rhabdomys pumilio, and other murid rodents as hosts for immature ixodid ticks', Onderstepoort Journal of Veterinary Research 71, 313-318. PMid:15732458

Skinner, J.D. \& Smithers, R.H.N., 1990, Mammals of the southern African subregion, University of Pretoria, Pretoria.

Spickett, A.M., Horak, I.G., Van Niekerk, A. \& Braack, L.E.O., 1992, 'The effect of veldburning on the seasonal abundance of free-living ixodid ticks as determined by drag-sampling', Onderstepoort Journal of Veterinary Research 59, 285-292.

Spickett, A.M., Gallivan, G.J. \& Horak, I.G., 2011, 'The dynamics of questing ticks collected for 164 consecutive months off the vegetation of two landscape zones in the Kruger National Park (1988-2002). Part II. Rhipicephalus appendiculatus and Rhipicephalus zambeziensis', Onderstepoort Journal of Veterinary Research 78(1): Art. \#233, 9 pages. doi:10.4102/ojvr.v78i1.233, PMid:1297958

Theiler, G. \& Salisbury, L.E., 1959, 'Ticks in the South African Zoological Survey Collection - Part IX - "The Amblyomma marmoreum group",', Onderstepoort Journal of Veterinary Research 28, 47-124.

Uys, A.C. \& Horak, I.G., 2005, 'Ticks on crested francolins and vegetation in Limpopo Province, South Africa', Onderstepoort Journal of Veterinary Research 72, 349-343.

Walker, J.B., Keirans, J.E. \& Horak, I.G., 2000, The genus Rhipicephalus (Acari, Ixodidae), a guide to the brown ticks of the world, Cambridge University Press, Cambridge. 